\title{
Cultivating urban conviviality: urban farming in the shadows of Copenhagen's neoliberalisms
}

\author{
Rebecca L. Rutt ${ }^{1}$ \\ University of Copenhagen, Denmark
}

\begin{abstract}
In this article I explore how the possibilities for commoning and conviviality through small-scale urban farming initiatives intertwine with neoliberal trends. I do this by recounting the trajectory of a small rooftop garden in the city of Copenhagen, Denmark. Drawing on ethnographic research in and around this garden, I show how such communal, anti-capitalist, eco-social endeavors are thoroughly entangled in the city's neoliberal turn over recent decades. Various manifestations of neoliberalism, ranging from formalization processes to austerity pressures, articulate with convivial urban farming initiatives in contradictory and recursive relationships that both nurture and endanger these local initiatives. I describe for example how formalization engenders legitimacy but also homogenization and how green initiatives are celebrated while undermined by austerity measures. This happens within a broader context of neoliberal labor, food systems, and housing policies and politics that subvert convivial urban farming efforts in multiple and often unacknowledged ways. Finally, I forward the view that attending to such contradictory and complex realities of and surrounding urban farming is essential to illuminating the iterative relations between context and practice, and the actions required at multiple scales to nurture and expand the possibilities for urban commoning and conviviality, including through farming.
\end{abstract}

Key words: the commons, urban farming, neoliberalism, Copenhagen

\section{Résumé}

Dans cet article, j'explore comment les possibilités de mise en commun et de convivialité à travers des initiatives d'agriculture urbaine à petite échelle se mêlent aux tendances néolibérales. Je le fais en racontant la trajectoire d'un petit jardin sur le toit dans la ville de Copenhague, au Danemark. En me basant sur des recherches ethnographiques dans et autour de ce jardin, je montre comment de telles initiatives communautaires, anticapitalistes et éco-sociales sont profondément mêlées au tournant néolibéral de la ville au cours des dernières décennies. Diverses manifestations du néolibéralisme, allant des processus de formalisation aux pressions d'austérité, s'articulent avec des initiatives d'agriculture urbaine conviviale dans des relations contradictoires et récursives qui nourrissent et mettent en danger ces initiatives locales. Je décris par exemple comment la formalisation engendre la légitimité mais aussi l'homogénéisation et comment les initiatives vertes sont célébrées tout en étant sapées par des mesures d'austérité. Cela se produit dans un contexte plus large de main d'œuvre néolibérale, de système alimentaire et de politique (incluant celle du logement) qui subvertissent les efforts d'agriculture urbaine conviviale de multiples façons souvent non reconnues. Enfin, je transmets l'idée que la prise en compte de ces réalités contradictoires et complexes de l'agriculture urbaine environnante est essentielle pour éclairer les relations itératives entre le contexte et la pratique, et les actions requises à plusieurs échelles pour nourrir et élargir les possibilités de mise en commun urbaine et de convivialité, y compris celles qui passent par l'agriculture.

Mots-clés: mise en commun, agriculture urbaine, néolibéralisme, Copenhague

\footnotetext{
${ }^{1}$ Dr. Rebecca Rutt is an urban gardener and Assistant Professor in the Department of Food and Resource Economics at the University of Copenhagen, Denmark. Email: rlr "at" ifro.ku.dk. Acknowledgements: I am very grateful to the respondents and fellow gardeners referred to in this article, to Prof. Jens Friis Lund for insightful comments during the writing process, to Prof. Simon Batterbury for exceptional support in publication, and to two anonymous reviewers for their encouraging and constructive feedback.
} 


\section{Resumen}

En este artículo exploro como las posibilidades comunalización y convivencia a través de iniciativas de agricultura urbana en pequeña escala se entrelazan con tendencias neoliberales. Para ello, relato la trayectoria de un pequeño jardín en la azotea en la ciudad de Copenhague, Dinamarca. Basándome en la investigación etnográfica este jardín y sus alrededores, muestro cómo estos esfuerzos comunales, anticapitalistas y ecosociales están fuertemente entrelazados con el giro neoliberal de la ciudad en las últimas décadas. Diversas manifestaciones del neoliberalismo, que van desde procesos de formalización hasta la imposición de medidas de austeridad, se articulan con iniciativas de agricultura urbana comunal en relaciones contradictorias y recursivas que nutren pero también ponen en peligro estas iniciativas locales. Describo, por ejemplo, cómo la formalización genera legitimidad, pero también homogeneización, y cómo las iniciativas verdes son alabadas a la vez que socavadas por las medidas de austeridad. Esto sucede dentro de un contexto más amplio de trabajo neoliberal, sistemas alimentarios, políticas de vivienda y ambiente político que subvierten los esfuerzos de agricultura urbana comunal en formas múltiples y a menudo no reconocidas. Finalmente, planteo la idea de que prestar atención a las realidades contradictorias y complejas de la agricultura urbana y su entorno es esencial para aclarar/entender las relaciones iterativas entre el contexto y la práctica, y las acciones requeridas a múltiples escalas para nutrir y expandir las posibilidades de comunalización y convivencia urbana, incluso a través de la agricultura.

Palabras clave: comunalización, agricultura urbana, neoliberalismo, Copenhague

\section{Introduction}

A garden is a nursery for nurturing connection, the soil for cultivation of practical reverence.

- Robin Wall Kimmerer (2013: 155)

It's hard to keep voluntary projects alive without life in the space. (...) When there's no life, there's only responsibility left.

- A longtime activist on a neighborhood walking tour of struggles over green spaces in Nørrebro, Copenhagen, 2019

$\mathrm{TOP}^{2}$ is a little rooftop garden started in 2010 in the Copenhagen neighborhood of Nørrebro. Its members call it the "oldest community rooftop garden in Copenhagen." Around 20x30 meters, TOP is organic, communal, and home to raised beds, a small greenhouse, and several beehives. A Facebook page states its mission:

[TOP] (...) works to spread the message of a greener Copenhagen (...) By using the city's space for cultivation, TOP will show how vegetables' way from soil to table can be made considerably shorter. Many of the goods we buy in the supermarket are produced far from Nørrebro and far from Denmark. With (...) cultivation in the city, we can [take action on] the bad condition of the climate. Everyone is welcome to participate.

Praised in local and national media, a major newspaper recently proclaimed, "[TOP] (...) opened Copenhagener's eyes to what urban gardens and green communities can do" (Elsøe 2015).

TOP represents a growing trend of celebrating urban farming within Denmark and globally. Researchers have argued that urban farming may contribute multiple environmental and social benefits, including food security, physical and mental wellbeing, skill-building, community development, food systems change, climate change resilience, better air quality, and more (Dubbeling and de Zeeuw 2011; Horst et al. 2017; also see Christensen, Dyg, and Allenberg 2018 for a helpful review). Public sector support for urban farming has

\footnotetext{
${ }^{2}$ TOP is a pseudonym, although I acknowledge anonymity cannot be guaranteed. Please see the methods description further
} down for a more detailed account of respondent consent. 
followed suit. And while food production in cities has a long tradition worldwide, recent decades have seen urban farming embraced by more and more people in 'developed' countries due to the intersection of expanding sustainability and justice discourses, critiques of industrialized agriculture, concern for the effects of climate change, and a felt need for community-building, alternative collectivities, and better material relationships with the natural world (Berglund 2017; Mok et al. 2014; Schlosberg and Coles 2016; Taguchi and Santini 2019).

I loosely define urban farming (or urban agriculture) as the cultivation of food within metropolitan areas, encompassing activities such as growing vegetables, fruit, herbs, and grains and raising fish, bees, and animals (Horst et al. 2017: 280). Urban farming is not one thing. Its varieties range from expansive peri-urban to smallscale 'guerilla gardening', for-profit to subsistence, and individual to communal. The multiple forms and diverse rationalities of urban farming - and the contexts within which they develop - are key to understanding its development, potentials, and risks (McClintock 2014: 148; Christensen, Dyg, and Allenberg 2018). In this article, I forward a view on urban farming that takes this multiplicity and contextualization seriously. I aim to counter universalizing messages about potentials and risks of urban farming, and instead, bring out the complexities of what happens in and around spaces called urban farms and illustrate the need for research that is mindful of context, in particular, the nature of municipal and national development trajectories. I do this based on a study of TOP, a community-run, not-for-profit, small-scale communal garden in a diverse but gentrifying neighborhood of Copenhagen, Denmark, a well-off European city widely praised for its sustainability leadership (EC 2014).

Yet TOP has evolved over the past decade not only in terms of its ecological configuration but also its governance approach, membership demographics, and tenability within the city. Interest in crafting Copenhagen into a 'green city' emerged in recent years. Rutt and Loveless (2018: 111) describe that "green spaces have become integral to neoliberal transformations in Copenhagen, playing a role in strategies aiming to 'sell the city"' to higher-income residents (also see Tubridy 2020). At the same time, Copenhagen is also moving along other socio-economic pathways, as is Denmark, which is now described as a "historically welfaredriven, but increasingly neoliberalized state" (Roy 2018: 290). A 'welfare commitment' remains, even if it is occasionally co-opted in the service of the larger neoliberal agenda (ibid.; also see Larsen and Andersen 2009).

In this article, I wish to examine the practice of urban farming in this context of an increasingly neoliberal Copenhagen. I will distinguish amongst neoliberalism's multiple faces, showing how its diverse manifestations - as formalization, austerity, a productivity imperative, corporatization/industrialization, and deregulation and gentrification - shape the possibilities for projects of commoning and conviviality in contradictory ways. I will also reflect on how conviviality and commoning can grow in the practice of urban farming. I assemble this article on the basis of ethnographic inquiry over nearly six years, during which I was (and remain) a member of the garden's governing association including serving three years as a board member. Insights come from countless informal exchanges and observations over the years in the city, with members from TOP and nearby gardens, and with representatives from the public sector (Copenhagen municipality) and other local institutions such as environmental and social organizations. Five formal, semi-structured, transcribed interviews with 'key' respondents provide most of the material quoted in the article: one of the association's founders, one previously on the association board, and three from public/municipal institutions that have been deeply engaged in supporting urban greening and farming in the neighborhood. These are the neighborhood 'Local Committee' (constituted by elected local association representatives and political parties, serving as the "link between residents and the Citizen Representation at City Hall", see Nørrebro Lokaludvalg 2019), the city's Technical and Environment Administration, and the neighborhood Area Renewal (existing within the Technical and Environment Administration, with responsibility to "lift the neighborhood physically, socially, and culturally" over the period 2014-2019; see Områdefornyelsen Nørrebro 2014). ${ }^{3}$ I also reviewed media coverage, other academic inquiries into urban farming in Copenhagen, and relevant official documents (public policies, reports, etc.), translating into English where required.

\footnotetext{
${ }^{3}$ All respondents gave oral consent prior to being recorded for interview and the use of interview content for academic publishing. Three respondents quoted most received the article in full draft form over a month in advance and were encouraged to review to ensure the account herein is valid and acceptable for publication.
} 


\section{Conceptual framing}

In this article I draw on urban political ecology. With its "distinctly Marxist origin", urban political ecology seeks to shed light on "the ways capitalism not only produces cities but also produces nature in cities at the same time" (Heynen 2017: 1). While the field emphasizes the interconnectedness of socio-natural processes, it is particularly interested in social power relations, as sites of agency and responsibility in determining who accesses and/or controls valued aspects of the city and on what terms. The political program of urban political ecology is "to enhance the democratic content of the socio-environmental construction [of urban metabolisms] by means of identifying the strategies through which a more equitable distribution of social power and a more inclusive mode of the production of nature can be achieved" (Heynen 2017: 8).

Political ecology takes a special interest in the ideology of neoliberalism. I approach the process of 'neoliberalization' as a beast of many faces. Echoing the evolution of political ecology to focus on "how power manifests itself in both discursive and material struggles" (Svarstad and Benjaminsen 2020; also see Forsyth 2003 and Robbins 2012), I emphasize both structural (e.g. material) and post-structural (e.g. discursive) elements of processes of neoliberalization, in relation to the practice of urban farming in Copenhagen.

Neoliberalism's structural manifestations include austerity, corporatization/industrialization, deregulation and gentrification, and the productivity imperative. Structural elements feature prominently in, for instance, the work of geographer David Harvey, who viewed neoliberalism as a distinct form of capitalism aimed at 'accumulation by dispossession.' This entails an array of largely state-enabled mechanisms including privatization (entailing e.g. corporatization and industrialization) as well as austerity politics and strategic regulation and deregulation (Harvey 2007a). These mechanisms have also been viewed temporally in terms of their contributions to the 'rolling-back' of "Keynesian-welfarist and social-collectivist institutions" so dominant in the 1980s, to the 'rolling-out', that is consolidation of "neoliberalised state forms, modes of governance, and regulatory relations" to follow Peck and Tickell (2002: 384). These mechanisms also enable neoliberalizing cities to compete to attract particular social groups, namely asset-rich residents, as well as investor capital (Harvey 2007b). Thus the neoliberal project of accumulation is capitalist in nature, geared toward the acquiring of wealth from the many, for the few. While I do not reflect explicitly on specific accumulation outcomes from urban farming, I do engage with the associated mechanisms, keeping their implications always in mind.

By 'productivity imperative', I refer to pressures to produce and perform at increasingly higher levels that characterize the lives of most individuals in liberal democracies like Denmark. Such pressures are visible in recent trends in such countries to increase, as opposed to the historical tendency of decreasing, the work week even though productivity is increasing, alongside the reduction of paid holidays and extending the retirement age. Individuals' paramount roles under economic growth-oriented development policies (as capitalism writ large) are 'laborer' and 'consumer.' Put simply, "The laborer (a person) sells labor power (a commodity) to the capitalist to use in the labor process in return for a money wage which permits the laborer to purchase capitalistproduced commodities in order to live in order to return to work" (Harvey 2000: 102). The cycle is maintained in part by the logic of scarcity and 'positional goods' framed as key to 'the good life', creating an endless pursuit of material (and inevitably social) exploitation (Kallis 2015). The acquiring of goods beyond basic needs in many societies today serves mainly to signify "one's position in society and depends on relative income. (...) Positional goods are inherently scarce since scarcity is their essence; by definition, not everyone can have high status" (Kallis 2015: 167). In the neoliberal context of strategic (de)regulation, even access to basic goods like housing are increasingly threatened. This condition characterizes Copenhagen as many other cities today (see Larsen and Lund Hansen 2015). And in today's 'gig economy' of precarious employment, widespread debt "cannibalizes labor", "suck[ing] value from households, families, communities and nature" and transferring it to an elite few (Fraser 2016: 113). Thus, the general public works, consumes, seeks status vis-à-vis consumption and/or scrambles to manage its precarity - while socio-economic elites profit. Local initiatives meanwhile deteriorate, despite their good intentions, and I will elaborate further in the discussion how these structural elements interact with urban farming in myriad ways.

Neoliberalism is also usefully approached from a post-structural perspective. Here I am inspired by Nightingale's (2005: 582) distinction of neoliberalism as both "an economic programme" as explored by David Harvey and others, and "a set of ideas about the appropriate mechanisms for social and economic progress" 
(also see Peck and Tickell 2002). The latter entails neoliberalism's discursive elements, which Nightingale explores through examining how professional and expert knowledges are promoted and embedded in diverse activities and procedures (in her case, within community forestry) and particularly, the ways in which associated practices undermine official goals of inclusion, democracy, and ecosystem health.

Nightingale explains how legitimacy to govern valuable resources is embodied in particular, privileged forms of knowledge that promote market approaches while reconfiguring social relations, including recreating ideal visions of 'community.' Considering the 'community' in the urban gardening context, Mok et al. (2014: 24) describe it as the quality of facilitating exchange "across generations and cultures, societal development, and empowerment." Christensen, Dyg and Allenberg also acknowledge the term 'community' is a "conceptual minefield", but settle for a definition of 'community gardening' as, "the quality that they involve convergence of individuals - members of the community - joining in garden activities open to the public" (2018: 233-234). The authors invite distinguishing the diverse rationales of actors encountering each other around community urban gardening. More than rationales, Nightingale (2005: 584) also reminds that,

Which users embrace the discourses and practices of professionalism and for what purposes lends insight into the workings of neoliberalism and how it is implicated in the reconfiguring of social and power relations within localities and (...) the consequences of this for ecological change.

Following these cues, I explore encounters within and around the TOP 'community.' I use the term 'formalization' to indicate aspects of 'expert' knowledge and the iterative alignment of an urban garden association's practices with dominant governing norms - and the effects this has on the association's demographics (through which social and power relations are manifested). Thus, my use of formalization resonates with Nightingale's 'professionalization' and its linkages with bureaucratization - that is, processes supporting and supported by bureaucracies.

To see beyond neoliberalization's multiple forms and its nefarious implications, and to imagine the city differently, I draw inspiration from degrowth scholarship as it pertains to the urban context. 'Degrowth', an increasing movement of academics and activists, aims at "achieving a radical change in the societal metabolism of societies, toward a more frugal, sustainable and convivial lifestyle" (Gomiero 2018: 1823). Ideas of conviviality, commons, care, and justice stand at the foreground of the degrowth discourse alongside the decentering of economic growth as the dominant development aspiration and indicator of wellbeing. Conviviality for instance is a "living practice" (alongside its more ideological form, 'convivial-ism'), promoting reconsideration of wellbeing, 'the good life', and what it means to live together - recognizing social relations rather than material accumulation as "our greatest treasure" (Adloff 2016). Such alternative understandings of a good life may upend the scarcity logic of positional goods and by extension, the productivity imperative altogether - if structural precarity can be managed.

The 'commons' and the active 'commoning', illuminate the social practices required to do so. Commons entail "a vast array" of non-capitalist self-provisioning and governance spaces and systems that largely function as "a social glue"; a resource becomes 'commons' only "when it is taken care of by a community or network" (Helfrich and Bollier 2015: 103). In other words, at the heart of such commons is not an open access resource, but something collectively cared for. Community urban farming projects are an obvious contribution to a growing catalogue of concrete actions ripe for cultivating conviviality and commons in the pursuit of future degrowth trajectories (Anguelovski 2015; D'Alisa, Demaria and Kallis 2015).

\section{Historical, situated, and policy contexts}

To understand the entanglements of urban farming and neoliberalism, it is essential to recognize not just a garden's particular form and its driving rationalities, but also the context within which it has developed and how such "socio-physical constructions" are "actively and historically produced" (Heynen 2014: 7; McClintock 2014). 


\section{History of UF in Copenhagen}

Urban farming has been practiced in Copenhagen for centuries. In the late 1500s, land beyond city embankments (which within firing range and should remain free of construction) was designated by the monarchy for gardening as a poverty relief and social improvement initiative. The ambition was to provide poor residents with an 'educational' leisure activity alongside fresh air, fruits and vegetables - while inhibiting alcohol consumption (Jensen et al. 2012; Kolonihaveforbundet n.d.). The now popular 'allotment gardens' of Denmark, constituted by small private plots for food production, are a relatively newer phenomenon that emerged alongside industrialization at the end of the 19th century. Publicly owned land was provided near urban centers for the mushrooming working class to compensate for increasingly poor housing and working conditions (Kolonihaveforbundet n.d). The allotment garden 'movement' thus has strong historical connections to labor and union movements, a "symbol of the blue collar culture" (ibid.; Denmark.net 2020). Gardeners, working their own small plots side by side in a delimitated space, soon organized into associations to improve management amongst themselves and tenure conditions vis-à-vis the municipality; in 1908, the overarching association of Allotment Gardens Associations in Denmark was established. In the inter-war years, allotment gardens reached a maximum of approximately 100,000 across the country (Jensen et al. 2012). Yet many dissolved over the decades due to municipal or state repossession for development projects. Pressure from the Association led to the hard-won Allotment Garden Act of 2001 that enshrined stronger tenure for garden associations, preventing "the Danish allotment garden culture from disappearing" altogether; currently there are around 60,000 (Kolonihaveforbundet n.d.; Hansen 2009).

Urban allotment gardens thus have a long history in Denmark but urban community gardening is a relatively new phenomenon. This stands in contrast to the USA, for example, where projects blossomed from the early 1970s (coinciding with the burgeoning environmental movement). While allotment garden associations are certainly a type of community, only in 1994 was the first 'community garden' established in Copenhagen, distinguishable by the communal approach to management and produce distribution. The following year the Network of Urban Gardens was founded to assist these grassroots initiatives (Jensen et al. 2012). While there is no record kept of community gardens in Denmark, recent estimates point to over a hundred, and at least fifteen in Copenhagen (Ritzau 2015). Many of these exist (or existed until recently, keep reading for details) in the Nørrebro neighborhood.

\section{Neighborhood history}

Nørrebro emerged as a working class neighborhood of Copenhagen in the mid-19th century, comprised largely of rural Danes pursuing employment during the early days of industrialization (Dansk Byplanlaboratorium 1996). Nørrebro was also a popular destination for migrants from outside Denmark, many at that time from Sweden and other northern European countries (Schmidt 2017). The neighborhood became crowded as the burgeoning population crafted more living spaces out of backyards and corridors. Most families occupied two-room apartments, many lacking toilets and hot water, and all relied on coal for heating, prompting respiratory illnesses (Dyck-Madsen 2004). Still, a rich community culture flourished. Due to its demographic and occupational composition, Nørrebro grew into a hub for the national workers' movement (Schmidt 2015). During the late $19^{\text {th }}$ and early $20^{\text {th }}$ centuries the area was also referred to - derogatorily - as the 'Rhubarb Quarter.' Rhubarb was one of several crops frequently grown there by peasants who came to become urbanites, but who did not leave their farming skills behind in the fields.

Nørrebro was one of the city's first neighborhoods to experience urban 'renewal' post-WWII in the form of demolition and reconstruction. While extremely contested, these actions reopened many inner apartment block courtyards, which eventually paved the way for more public green spaces, including for cultivation projects (Rutt and Loveless 2018). Meanwhile, over the span of a few decades, Nørrebro's demographics shifted with an influx of migrant families also from beyond European borders (KK 2012). This trend was stimulated by social housing programs since the 1980s prioritizing low-income residents, and because of the neighborhood's tradition of solidarity with marginalized groups (Larsen and Möller 2013; Steiger 2017). Denmark has also struggled for decades with integration challenges, propped up by persistent xenophobia 
(Zucchino 2016). Facing unemployment and social exclusion, some 'migrant' youth in Nørrebro have, especially since the 2000s, turned to gangs to obtain income, identity, and sense of belonging (Pedersen and Lindstad 2011). Nørrebro also hosts several homeless shelters, welcoming Danish, European, and increasingly, nonEuropean homeless migrants (Project Udenfor 2012). The neighborhood of Nørrebro retains a strong identity with close links to the past. ${ }^{4}$ The label of 'Rhubarb Quarter' has been reclaimed: the neighborhood has proudly been one of the city's richest for urban gardening projects, although many of these have come and gone, as I will discuss throughout this article.

\section{Policy and political context}

Copenhagen has pursued an urban 'green' agenda especially since the mid-2000s, driven by sharp awareness of the range of benefits this agenda can provide. The city now prides itself as being a "livable green city" (KK 2019), receiving the European Commission's 'Green Capital Award' in 2014 (EC 2014). This has included the creation or renewal of biophysical green spaces, though the agenda largely favors efforts within the energy and transport sectors (the 'grey' end of the 'grey to green' continuum of urban green infrastructure (see Roe and Mell 2013) visible not least in the widely praised Copenhagen Carbon Neutral Climate Plan 2025 (KK 2012b). In 2009, the City Council unanimously adopted the Climate Plan for Copenhagen to reduce $\mathrm{CO}_{2}$ emissions by 2015. The key strategy document released that year outlined "visions and goals for urban life", introducing city officials' "vision of being the world's eco-metropolis by 2015" (KK 2009). They note,

More green and blue areas (...) invite people to take part in urban life. A varied urban life gives us an advantage in the competition with other large cities. It attracts tourists, creative people and firms. It creates economic growth as well as painting a positive picture of both the city and business and cultural life. (KK 2009: 5)

Biophysical green areas are now integral to the city's brand and development strategies, embraced within its overarching green growth agenda. Economic growth is not only an explicit intention for city development (see the 'Ambitious Growth Policies' at KK 2015a), it is even at the foreground of the city's subsequent Climate Plan 2025; growth is mentioned 48 times in the 61-page document (KK 2012b).

In 2008, "inspired by the world's leading cities", Copenhagen also "focused on integrating green roofs as part of urban development" (KK 2013: 3). A 'green roof' policy in 2010 to ensure vegetation on appropriate new buildings was part of the package to achieve the city's carbon neutrality ambitions by 2025 (Lauritsen 2015). Green roofs were seen to provide "a multitude of benefits in a single location without reducing development space. Green roofs cool our cities, enhance biodiversity and reduce rainwater runoff. They also bring beauty (...)" (KK 2013: 3). In TOP's case, roofs can also provide food and a chance to practice farming in the city.

\section{Community}

Urban farming seemed to have come to the attention of municipal officials over the past decade. In 2010, a city official inspired during a visit to New York City, returned home with a mission to cultivate something similar in Copenhagen (as said in an interview). Ten million Danish kroner (approx. US\$1.5 million) were soon secured to support green projects with 'green volunteers' in the city (ibid.) And in the Nørrebro neighborhood's renewal initiative that ran from 2014-2019, 'Urban farming' was central to the new vision, including a goal of "a minimum of 10 new spots with urban farming by 2019" and a budget of 4.75 million Danish kroner (approx. US\$680,000; Områdefornyelsen Nørrebro 2014: 43). While it was challenging to pinpoint exactly how much financial support has been directed toward urban farming over the past decade (and certainly, money matters), it seems clear that municipal interest was on the rise. In this article, I argue that urban farming is a part of a

\footnotetext{
${ }^{4}$ However, some argue this is under threat due to broader xenophobia and gentrification (see Schmidt 2019).
} 
broader trend in the city, yet one that is persistently threatened under concurrent neoliberal and growth-oriented agendas.

\section{The evolution of TOP}

We now return to TOP, an initiative conceived by three people driven to grow food in the city by diverse motivations. One founder described the garden's origins:

My main concern was climate change and carbon footprint regarding food production. [Another] has an art historian background, and her thing was changing the cityscape, to give access to more non-monetary activities. And [the third], I think (...) he brought in these ideas about therapeutic effects of working with plants, and soil... So we had these different departure points and they connected quite well in the formulation of the [TOP] idea.

Copenhagen neighborhoods have local councils (lokaludvalg) elected from a pool of local institutions, from sports associations to political parties. It was at a 2010 council meeting where neighborhood 'greening' was on the agenda that one suggested gardening, and the three strangers came together in shared interest. One explained,

I came to the meeting and said, 'how about if we grow food?' Some said, 'Ah, you need to move to the countryside!' I was bothered by that, but after the meeting, [the others] approached me. We huddled up and agreed, 'we need to do this.' For me, it came out of a frustration of the climate summit in 2009. I was part of the activist groups that held different projects up until and during the meeting. There was this feeling of [a] new regime, and we need to do something. And [the others] had the same feeling.

Agreeing on the name 'TOP', the small group became an 'official' association through an administrative registration process. The next step concerned logistics - where and how to get space to grow plants in the city? "We showed up everywhere we could and said, we are TOP, we want to do this. We want to produce food in the city." Ideas for how were brainstormed and discarded. Mobile raised beds for example were quickly abandoned due to cost. Then networking proved fruitful. Engagement at a neighborhood house led to the discovery of a primary school rooftop nearby. "[The school principal] didn't take much convincing. (...) I think we only had one meeting and he was like, 'Go for it!"' Early small-scale finance was soon fundraised from city and state resources and the garden began to take shape (Figure 1, 2, 3).

Alongside the development of the physical space, the formalization of TOP as an association and social endeavor also advanced. This process came to embody a growing contention in the little garden, eventually threatening its very existence. What did formalization look like? Here, it was visible in the early uptake of ostensibly hierarchical structures such as an elected board, in the later documentation of a constitution and rules of membership, and through the continued establishment of relations with public authorities whereby TOP had to demonstrate its legitimacy. More concretely, it was visible in the eventual internalization or embodying of these bureaucratic aspects as integral to the garden by a growing share of members, and a more hierarchical approach to governance.

One founder explained how in their early days, to be taken seriously,

We had to form a board. We were three people. I became the chairperson. We discussed different people that could be interested to [take part], but ended up just having some of my friends on the board, who knew a bit about things... So now we had a board, the smallest we could get away with. 
Some in the group struggled with this perceived imposition of bureaucracy by the municipality. "Basically what we wanted to do was just dig soil and plant plants, so [the need to form an association and board] felt somewhat of an obstacle, to get to where we wanted to go." This sentiment is not unique to TOP. Volunteers behind a nearby street-level community garden, which for a time was a showcase community garden for the municipality (Laage-Thomsen and Blok 2020), also resisted these requirements. A city representative described to me their reaction,

They got very provoked. Really annoyed. But they ended up just doing it. For them, it meant that they had to fit into this certain box that they didn't want to fit into (...) to get the partnership with the municipality and the temporary right to use the area.

For some, like one of TOP's founders, it also represented something significant. Despite some frustrations, "As I remember it also felt like, ok now we're serious."

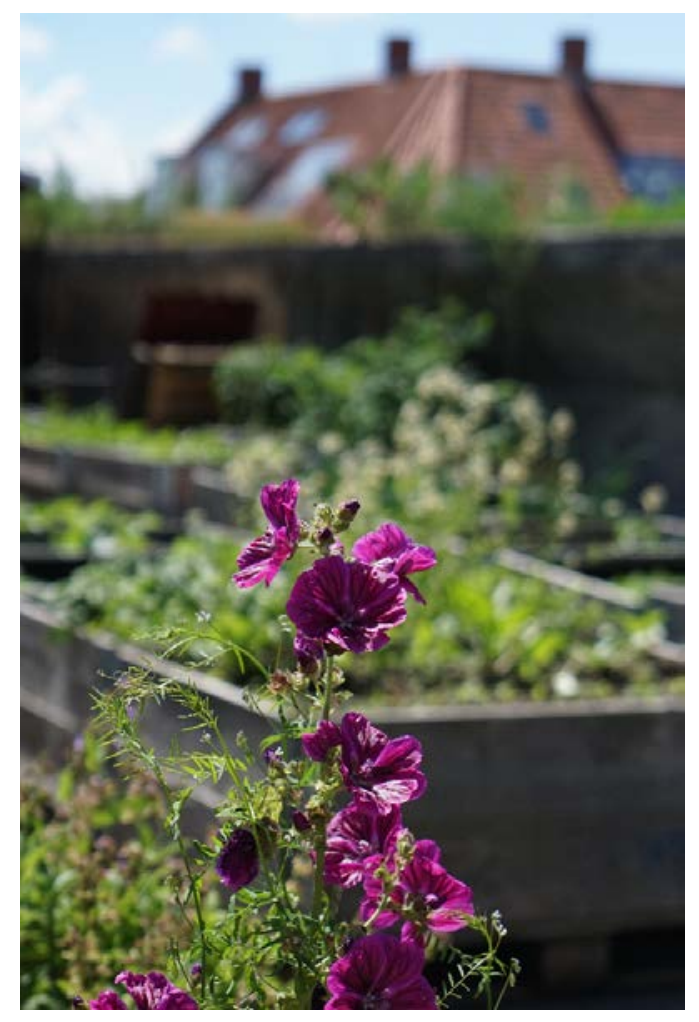

Figure 1: A flower in the garden. Photo by author.

Dreams grew alongside the physical space. One aspiration entailed a comprehensive reconstruction and reconceptualization of the garden into an integrated educational space, in close collaboration with the school below - at a cost of millions of Danish kroner. Such a project could mean paid employment for two of the three founders, all of whom were experiencing uncertain employment. One came from a financially secure background but the others were more vulnerable, one working several part time jobs, the other relying on statesupplemented unemployment benefits. The latter described, "I was more or less full time up there. If it hadn't been for [unemployment insurance; in Danish dagpenge, it wouldn't have been possible." A fundraising application was assembled and even initially accepted by a large private donor. Yet by the end, success was 
elusive due to rejection by the municipality which had to co-support the endeavor. A municipal representative explained their interpretation of the process,

They had a good project description (...) but they didn't at all have a clue about how, if you want to have such a huge amount of money, you have to be organized, and have some kind of agreement with the school, and the municipality, about what it meant, all these things they were writing in the description [versus] reality.
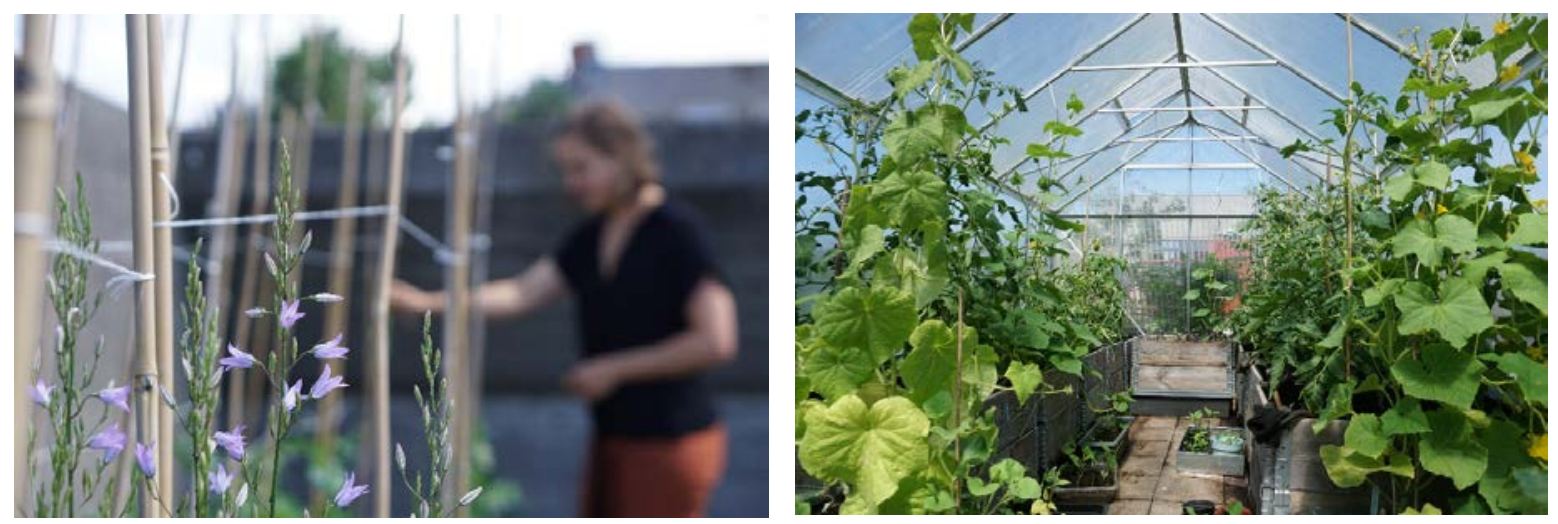

Figures 2 and 3: The garden and its greenhouse. Photos by author.

Thus the garden founders' attempt to be recognized (seeking integration into the formal municipal system) and radically transforming the potential of the space was rejected on grounds of their not yet being 'mature.' As the grander ambitions were put to rest, TOP continued as a small community garden, expanding with more raised beds, a greenhouse (Figure 3), and composting and sprouting stations.

As TOP's membership also slowly expanded, a shift became apparent. Two members joined in late 2013, who would embody this shift. One described TOP at that time:

They were kind of, very laid back. They were like, 'Come up as much as you want! We really need help! We have many great ideas and want to make them happen!' So we really thought we could contribute to the organizational structure, and helping it grow to its full potential, alongside a lot of gardening.

To this member, 'full potential' entailed "getting the organization out to more people. Getting the space recognized." And the way to achieve this potential in the eyes of these new members was to create a more 'professional' organization, harnessing their knowledge and experience of financial accounting and board management. The member described her and her partner's major contributions:

Definitely getting the financial situation under control. When we joined the financial situation was a [often] in the minus, where the members had to contribute to make it go to zero, which was not good for an organization. And we made it legal in some sense. You have to have a board to have an association. (...) And at that point, they did have it of course, but it was basically the three of them, and more or less pro forma, for show. (...) And we came, and we helped them. 
These actions thus developed the association in a way that, importantly, signaled its legitimacy to authorities such as municipal funding decision makers and the school administration. One of TOP's founders acknowledged the change when these two joined: a valued contribution in his opinion, but also one that gave rise to discomfort in others. Despite that discomfort, these two members quickly came to be amongst the most committed, eventually leading for several years in organizing, fundraising, and gardening activities.

It was late 2014 when I joined, discovering the roof by accident through a pop-up dining event. By this time one founder had moved on and new volunteer members like me were flowing in. Many expressed a dream of getting "soil under their nails" and through that, apparently, (re)connecting with nature and a community of like minds. I fell in love with the space and especially, its communal approach to both maintenance and food sharing as opposed to individualized beds. At the first meetings I attended, membership fees were being considered for the first time (it had been free for me, at first). We were perhaps ten people at the meeting although the official volunteer headcount was much higher. Despite some protests over the potential exclusions engendered by fees, one of the founders pushed in favor, arguing this could secure stronger member commitment. He seemed surprised with himself at taking this position, but arrived at it in the wake of rapid member turnover and perceived lack of commitment. The debate generated strong contrary positions but in the end, a small annual fee (around US\$30) was agreed upon. In later months, another major disagreement emerged over the possibility of having chickens on the roof. How could we ensure appropriate care for animals when we were intermittently struggling to keep our plants in good health? According to some, chickens would require strict procedures to ensure animal welfare - but this kind of language clearly rubbed some the wrong way. The points of disagreements started to seem endless.

At the root of it all appeared to be a growing distrust amongst some in the group regarding each other's intentions and values. This distrust, I came to observe, seemed rooted within a clash of ideals about how common space should be governed. While a general homogeneity among the membership in terms of apparent cultural/ethnic background was quickly apparent, the divide I am describing was distinguishable largely between those with full time (often 'white collar') employment / university enrollment, and those with part / unemployed status. Formalization was advancing, and it was not a passive trajectory. Rather, it was embodied and embraced by certain members and pushed by the overarching bureaucratic norms of the city. And the debate and tensions it produced were increasingly palpable.

By 2015 tensions boiled over. A disagreement - on the surface associated with the debate over the chickens - led to a physical fight between two longstanding members. The chairperson at the time, uninvolved in the incident, expressed sorrow and a compulsion to resign from the association altogether. In a post on the internal digital platform he explained:

We tried in 2014 to move [TOP] in a more structured way and create some formal framework for decisions and responsibilities. It has been hard and required many long discussions (...) [I]n several areas it has been fruitful. (...) Money came in and there was a strong group who all put a lot of energy in the garden and association work. Unfortunately, there were also conflicts, both personal and professional, that started small and were unresolved long enough that they now seem deep and unsolvable.

Not long after the board voted to expel the instigator of the fight; key codes were changed, other members informed.

The association moved on, but the incident left a stain. The story was hinted at uncomfortably to new members. No one felt good about banishing a member, though relief for some was palpable. However, division following socio-economic contours persisted: the lower income, part time or unemployed persons calling for a 'flat democracy' against the more middle-income and/or full-time student 'professional' group and their ostensibly structured, hierarchical governance norms. I use 'ostensibly' as in practice TOP's board aimed to be accommodating; few refusals for e.g. events or changes were issued - although board questions or decision delays created irritation and some proposals were subsequently dropped. 'Accommodating' is clearly in the eye of the beholder. Distrust and gossip flourished. Most of the earliest members eventually left. We meet in the 
streets now and then, always with a warm greeting. But sentiments of a takeover remain, for some. Last year, a former member spontaneously complained how rules introduced 'in those days' had spoiled the atmosphere.

Membership turnover continued as seasons passed. This remained a source of irritation; an average member lasted for just one season. Those with more institutional knowledge were burdened with introduction and integration. New members must know their rights (e.g. introduce new plants, hold events), duties (e.g. commit to watering for several summer weeks) and security guidelines given the location on a public-school roof. Despite the turnover, some discord remained within the group. And in turn, the discord seemed to contribute to the turnover, as new arrivals landed in a context latent with tension. This seemed to be perpetuated especially by a vocal longstanding member - one of few holdouts from the earliest days. This member rejected the board approach to governance, using the roof and our social media to call for a 'flat democracy', the end of membership fees, and more decision-making autonomy. These calls were time and again rejected by the group at large; resentment then fed perceived personal attacks and minor conflicts. The mood became so toxic that in the spring of 2019 this member was also expelled by a reluctant board vote.

Over the years I have struggled to be a regular presence on the roof. Years back, I stoically accepted a role as occasional representative, fundraiser, and elected board 'alternate.' This eased my guilty conscience; I believe I have helped in numerous small ways to keep the project alive (if I sometimes wonder in a zombie-like state). I have seen numerous ambitious plans eventually scrapped. The chicken initiative never got off the ground. We aspired to reuse the space toward mushroom growing. A new member joined with this knowledge, but quickly departed to pursue a private endeavor. In fact, these days all members struggle to show up. Many of those most present on average over the years have departed; two actively removed, others at least partly driven away by the sometimes-toxic atmosphere that persisted. The two members who introduced new rules and structure to the organization have moved on. They were strongly affected by the negative climate, but also underwent a life transition with an expanding family and acquiring a larger allotment garden of their own. In fact, this represents a fulfillment of TOP's original mission, to serve as a hatching ground for the passion and knowledge of cultivating one's own food. Yet the context of struggle today does not imply we lack goodwill. On the contrary, we remaining 'TOPers' express ambitions and positive sentiments on our social media fora and aspirations for the season to come. When we do manage to come together, it is always reinvigorating. And requests by hopeful new members continue to trickle in. But what keeps inhibiting more meaningful involvement, visible for instance in more time actually spent on the roof together? Are there lessons that echo other well-meaning initiatives that struggle to endure in our region of the world?

One of the biggest barriers to the more active engagement with urban gardening, that 'soil under the nails' ideal I also imagined at the outset back in 2014, is sheer time. We make Doodle calendars that few manage even to complete. We create workdays and most explain away their absences. A general sentiment of embarrassment occasionally permeates (as evidenced in numerous apologetic posts replete with exclamation points and sad face emojis on our internal digital communications). As someone I initiated into TOP last year recently expressed to me in passing on her way to work, "I have a feeling of 'slacking off'! I have a guilty conscience, but I can't find the time!" This shortage of time we all perceive sporadically undermines our gardening (e.g. sufficient watering and weeding), but also undermines the face-to-face interaction so necessary for strong relations. Exacerbating disengagement particularly for urban farming is surely the ease by which we obtain fresh and healthy food. 'Food deserts' are few in Scandinavia. This suggests such projects are driven foremost by interest and/or values, a mix of drivers that are clearly important, but apparently insufficient. I know this reality is confounding other well-meaning community initiatives in this city, as surely they are across much of the industrialized world.

Today, TOP sits at a precipice. In the early spring of 2020 we re-established our board and initiated planting season discussions at the annual general assembly (around eight people turned up). Registered member count is down to 13 and we are opening for new members, prioritizing friends and family who are more likely to find the social connections they need to remain over the longer term. What I have found interesting to observe is the demographic / cultural context and shifts. TOP has never been reflective of the cultural mix of the surrounding neighborhood, but at one time we represented a range of incomes. Today, we are arguably more homogenous than ever; no voices challenge our governance practices. Yet there were voices in the past who resisted these norms. Those voices are now gone. And that, I argue, was not inevitable. Rather, it was an 
outcome of a specific development TOP underwent, itself reflective of hegemonic norms more broadly. This trajectory and outcome I will now set into the larger context of the neoliberalizing city.

\section{UF: valued activity or greenwashing?}

In late 2018, a major Danish news outlet 'Information' reported that

... 39 green volunteer projects in the City of Copenhagen have been told to close down from the beginning of the new year. This is due to politicians' decision to cut one position, the so-called Volunteer Coordinator, to close a gap in the Technical and Environment Administration's budget. (Wang 2018)

Many of these 39 projects involved urban farming. The Volunteer Coordinator position within the city's Technical and Environment Administration was created in 2012 to promote community-driven urban green initiatives, including urban farming. According to a respondent in the Administration, the position facilitated resident engagement in "city gardens, street cleaning, parking gardens to nature conservation projects in the city along with citizens, cows and bees." Facilitation mainly entailed help to navigate the bureaucratic context of obtaining permissions for example, creating contracts specifying terms of engagement, and understanding rights and rules. Groups were obliged to engage with the coordinator. The respondent described how the processes were often viewed by volunteer groups as a hassle, but also something that imparted security. The intention was "to clear up all those bureaucratic needs and demands, so [volunteers] could concentrate on the idea!", explained the respondent.

While some blamed financial mismanagement (Friberg and Ishøy 2019), the politically left-leaning mayor of the administration ${ }^{5}$ at the time was quoted explaining they were "'forced to make big savings' because the parties behind the entire municipal budget for 2019 provided 'large tax cuts to business by making the processing of construction cases free. At the same time, the [government] chose to spend millions on cheaper parking"' (Wang 2018). Her statement cast blame on rival centrist / right leaning parties which prioritized tax cuts and parking space commitments to their constituents. Indeed parking infrastructure, a "volatile flashpoint in Copenhagen's politics of mobility", is considered central to the wider neoliberal urban agenda prioritizing "market-oriented economic growth and especially private profit" (Henderson and Gulsrud 2019: 132).

Outcry followed the cut of the coordinator position by affected green projects and their social media networks and supporters. Fourteen affected projects petitioned against the decision in early 2019, calling it an "exceptionally bad decision" that will lead to deterioration in nature conservation and biodiversity alongside "thousands of direct citizen relationships" useful for addressing "many challenges of the future: biodiversity, integration, diversity, climate and sustainability" (Rosenberg 2019). Moreover, they claimed the decision undermined feelings of "legitimacy and credibility" among the city's volunteers: "The severely limited opportunities for partnership will mean that fewer voluntary forces will [initiate] new projects. Many volunteers have already felt, before the current decision, that parts of [the municipality] have been reluctant and incapable of entering into new and developing existing agreements and projects" (ibid.) The statement suggests a history of tenuous resident-authority relations in the city.

In response to the mounting criticisms, municipal actors claimed they were unaware of the implications for the city's green projects. The coordinator position had been added to a list requested by the Director at the time, of "people and areas that we could shut down, that wasn't something related to some kind of legal obligation... Something that was nice to do, but not that we had to do. [This] name and the green volunteer stuff ended up on that list", explained a respondent within Administration. After the firing and vehement public response, one politician was said to defensively claim, "'You don't need a volunteer coordinator to have volunteer projects. They can run themselves, it's easy. You don't have to spend money on that!", according to this respondent. To which other politicians responded, "'Hey, can't we see that list again, and research which

5 The City of Copenhagen has an elected 'Lord Mayor' and seven administrative units, each with its own 'mayor' allocated by proportional representation following municipal elections. 
projects can run themselves?' (...) They wanted to know more about it, instead of just saying, 'Ok we messed up. Let's undo this'." The respondent reflected on the implications: "it's counterproductive, because no one will say, 'We can't continue without a project coordinator.'(...) Why would they? I don't think [the green projects] have any interest in saying 'No we need to close down.' So these results (...) can kind of kill the whole idea of a Volunteer Coordinator." A second list was produced naming projects that "probably could survive." An Administration respondent described the subsequent reaction:

[a] co-worker wanted to save these projects, and in a misguided [way], said he could (...) just put it on his plate without extra cost. And that's what we really didn't want, because then we're going back to the way things used to work, (...) [with few] projects spread all over the city, with (...) different contact persons, different ways of doing it, and no expert knowledge on all the rules, permission, you needed.

Surely, a designated agent focused on facilitating community initiatives is a signal the city actually values its urban green projects.

Similar critique emerged of the municipality's widely praised 'City Nature' strategy for 2015-2025 (KK 2015b). Another municipal employee engaged with green projects described,

It came out and I was like, fantastic! Now I can put all the projects on that hook and it's going to be much easier. But it didn't come with any money and it didn't come with any plan, with any extra coordinating roles. (...) It's a symbol and it's a signal for the politicians to say, 'We would like to do this!' But its free to say that.

Budget cuts and symbolic actions obviously reflect priority tradeoffs, and are indicative of political imagination cut short. Even the left in Denmark is struggling to imagine something beyond neoliberalism, though they would rather be caught dead than associate with the term. A respondent in late 2019 explained that a 2018 budget cap (anlagsloft in Danish) meant, "all municipalities had to stop starting new projects, so there was also a stop in hiring new people. (...) Now it seems the whole mill is starting again, because of the new government." This was at a time in which the Danish national government was led by an economically liberal administration. In mid-2019 Denmark shifted politically toward the center left. Many including within the city Administrations are hopeful this shift will renew interest in green initiatives including urban farming. But was it ever truly at the foreground, or was it mostly greenwashing?

Meanwhile, TOP was quite safe. We simply "were on another [jurisdictional] list", explained a member when the news broke. Public administration of ground-level farms and gardens is rather straightforward, but TOP exists uncertainly at the intersection of several municipal jurisdictions. ${ }^{6}$ There simply was no precedent for a community association's use of a public-school roof. The jurisdictional dilemma remains unresolved and in fact, TOP never obtained a contractual agreement securing our investment on the roof. Why not, seemed to do with the bureaucratic uncertainty alongside changes in school leadership and uncertainties of whether a garden is the appropriate use for the space. ${ }^{7}$ Yet, TOP was thus unconnected to the Volunteer Coordinator, and the fallout from the termination. Interestingly, the rooftop is also in dire need of repair; teachers have complained to us of rain damage in their classrooms. Yet a lack of budget has prevented repairs, repairs that would require our departure. We often wonder, "when it will all be taken away?" - and by what mechanisms. Yet here I also want to shed light on the perverse mechanisms by which we are saved.

\footnotetext{
${ }^{6}$ These are, as far as TOP has been informed, the school administration itself, the administration for municipal buildings and property, and the municipal administration for children and youth.

${ }^{7}$ Following the rejection of the expansion project described earlier, compounded by the time deficit experienced by association members also described above, a deeper integration with the school has not yet manifested. This probably works against perceptions by the school administration of TOP's legitimacy there.
} 
In early 2020 I chatted with a municipal employee who has long promoted green volunteer projects including gardens, and another from Denmark's largest publicly subsidized social housing management organization, who supports resident-led green initiatives. I asked for their impression of whether Copenhagen prioritized urban farming. They laughed and quickly shared stories of challenges. I asked what the problem was. The municipal employee exclaimed, "bureaucracy!" The other, "cost!" They agreed: "they talk and talk, but when it comes down to it...." I was left to interpret the silence. I do so, as an indication of their frustrations with more talk than action. One raised the story of the rooftop farm 'ØsterGRO'. ${ }^{8} \mathrm{He}$ described how this farm 's has featured in official promotional materials (e.g. it is mentioned on the city's official tourism website, see VisitCopenhagen 2020). Yet in 2019 it faced closure because of a sudden, peculiar demand for more parking space. The municipality unexpectedly demanded 29 parking spaces on the property, with 23 approved for the rooftop. Garden members publicly responded: "If they are being frank when talking about the green transition, it makes absolutely no sense to demand that this unique example of exactly that, should be removed because of 23 fictional parking spaces" (Haaland 2019). General outrage by supporters was expressed across social media. ØsterGRO is still around today - the parking proposal seems to have been shelved, but the story as it circulates casts an embarrassing light on the city.

These stories of Copenhagen with its budget cuts, peculiar prioritization, confounded policymakers, and the impacts on projects like TOP shed light on the surrounding context within which such community projects struggle to survive - and the drivers of many of those same struggles. Cost-savings were priority number one last year, but clearly the collective action of resident groups have posed a threat to the city's reputation. I was later told the Volunteer Coordinator position was intended to be reissued.

\section{TOP in the shadows of neoliberalism}

TOP shows to varying extents how manifestations of neoliberalism contribute to shaping the possibilities for conviviality and commoning in contradictory ways. Neoliberalism manifests in Copenhagen in diverse forms, including but not limited to: formalization, austerity, the productivity imperative, corporatization/industrialization, and deregulation (e.g. of the housing sector) and gentrification. These forms reflect neoliberalism's structural (material) and post structural (discursive) elements.

Neoliberalism's austerity manifests and is maintained through intersecting strategies. Tax cuts for instance are enabled by the concomitant embracing of economic efficiency logics and thereby, particular technologies of governing. This echoes Nightingale's (2005: 582) description of neoliberalism as both "an economic programme and (...) a set of ideas about the appropriate mechanisms for social and economic progress." The often-discursive mechanisms include valorizing "professional and expert knowledges" (ibid.). These are embedded and promoted in activities even down to volunteer urban farms through formalization processes. From the practical requirement of formally registering as an association to the way in which being an association is performed, in this case via increasingly rigid structures, many of these mechanisms have also come to be embedded in TOP. With what implications?

Lang writes, "The State as a privileged actor of transformation ends up reifying relations of domination (...) instead of transforming them. (...) Instead, the State often transforms the transformers, demanding them to respond to certain rules and logics that are characteristic of state institutions but that obstruct transformational processes" (2017: 107). On one hand the broad municipal requirements for formalization have reshaped TOP in ways that challenged its very existence, undermining internal cohesion as certain members, well-suited to sustain the project due to their commitment and availability as only part-time or unemployed, felt threatened and alienated by the rule-bound and ostensibly hierarchical approach increasingly embraced by the association's evolving and increasingly more 'professional' membership demographic. On the other hand, formalization has also meant survival - in access to funding opportunities and building perceptions of the garden's legitimacy. Formalization in the form of rules introduced structures that aided the survival of the garden, regulating basic necessities such as sufficient watering in summer months.

\footnotetext{
${ }^{8}$ This is not a pseudonym. ØsterGRO is located in Copenhagen's Østerbro neighborhood. See: www.oestergro.dk. The building it sits on was once a car auction house, the roof used for display.
} 
Yet I do wonder whether the need for such rules was, in fact, an outcome of the evolution of the garden's membership demographic, where an increasing share of members face time constraints. We exist, as most within liberal democracies of today, under enormous, iteratively generated productivity pressures. Compelled by the city's growth oriented development policies (and capitalism more broadly) into fulfilling the dyadic roles of laborer / consumer (Harvey 2000), where 'productivity' is only understood in terms of what counts in existing societal metrics, these pressures sap the time we might put into pleasurable and regenerative voluntary activities like the garden. These pressures are upheld by dominant social framings of wellbeing whereby relative income and acquiring of goods (beyond basic needs) serve to signify one's position in society (Kallis 2015: 167), and/or by the pressures of precarity where neoliberalism's strategic deregulation threatens the security of access even to basic goods like housing (Larsen and Lund Hansen 2015).

Returning to the garden, could it survive run by bureaucrats and accountants alone? Surely not. And in TOP's case, most members who embody formalized approaches are also capable gardeners. Yet, despite aspirations toward being an 'accommodating' and 'flexible' association, the reality of those constraints we face (e.g. in time and capacity) restrict what we can achieve as a garden and as an association. Formalization has thus provided TOP a means to achieve and maintain legitimacy in the eyes of authorities, albeit with tradeoffs along the way. This is not unique. The other garden which like TOP faced internal dilemmas when required to formalize, also faced compromises in relations to aesthetic norms vis-à-vis the municipality. I recall an intervention by the municipality to standardize fencing to improve safety (it sat alongside a bike path); colorful hand-painted re-used wood was replaced by new, uniform fencing material. I remember garden volunteers observing this 'support' with unease. Laage-Thomsen and Blok (2020) describe a range of tensions produced by the dominance of official aesthetic norms, eventually contributing to the "dramatic termination" of the garden: it was bulldozed. The relation of this garden community with municipal authorities was characterized as "one of fragile collaboration and constant tension", "a series of compromises" from inception to end (LaageThomsen and Blok 2020: 14). The ambivalence they observe is interesting also in relation to TOP and more broadly given the ostensible support at the city level for such projects at the time (also see Halloran and Magid 2013). Like at TOP, Laage-Thomsen and Blok (2020: 15) note, "even amid this rather accommodating stance on the part of relevant authorities, the garden still struggles to achieve legitimacy vis-à-vis municipal ordering principles and practices."

And while formalization may provide access to resources and structures that support viability in this particular context, it can also bear nefarious implications for grassroots projects at large. This occurs not only by excluding certain types of people as described above, but also by handing over a project's legitimacy and security to the fluctuating values of the state, and by cultivating 'good citizens' who would not dream of just taking spaces for gardening (but rather only via official channels). This matters because power is never given, it is won - i.e. when the State has given something, it may more easily be taken away. This resonates with the history of allotment gardens in the country, before the introduction of the hard-won protective law in 2001 (Hansen 2009). ${ }^{9}$ Yet when something is won from the State, repossession is imagined less quickly, and more likely to be resisted. Meanwhile, the story of TOP showed how urban gardens and green volunteer projects become expendable when budget cuts and cost savings loom under neoliberalizing public administrations. Some scholars argue UF is "deserving of formalization" through for instance supportive regulation and public resources (Covert and Morales 2014: 195), acknowledging what official recognition has delivered in some impoverished neighborhoods. In Copenhagen, some urban green project volunteers seemed to appreciate guidance through complex bureaucracy provided by the designated municipal 'coordinator' - and were fearful when the position was terminated. I was told by several key respondents that only some groups - those well equipped with social (cultural and economic) capital - were successfully renegotiating contracts with the municipality under the new conditions. Peculiarly, this specific threat of closure did not affect us at TOP simply because of what felt like a fluke, our being on another list. Existing in a 'grey zone' and the consequent deficit of formalization here proved surprisingly useful. It allowed us to escape the fate of other gardens hit by the loss of the municipal volunteer coordinator position. "Hurray for grey zones!" we said to each other.

\footnotetext{
${ }^{9}$ Yet unsurprisingly, this law has come under attack by subsequent, 'growth-oriented' state administrations intent on retaking control for construction development (Kolonihaveforbundet 2019).
} 
Surely is there a role for public sector support, but perhaps in ways less well understood. Covert and Morales (2014: 201) posit that "formalization of previously informal activities" should contribute to "a richer civil society, deeper and more nuanced social experiences, and a more robust and resilient local economy." They describe the positive potential of formalized urban farming particularly for vulnerable groups (in this case immigrants and youth in the United States) as manifested through supportive municipal ordinances. Horst et al. (2017) similarly emphasize formal strategies for municipal support not just toward urban farming, but just urban farming such as improving rules toward secure access that explicitly prioritize more vulnerable groups. Yet Covert and Morales (2014: 201) also note, "formalization bears distinct consequences for practitioners of different types of agriculture (...) [which may] become pernicious and produce conflict between those identifying themselves with different types of [urban farming]" (ibid.). They point out that we know little of the individual, political, and social consequences of formalization and so call for greater scrutiny of such questions, something this article aims to deliver. Keeping in mind McClintock's call for a deeper contextualization of UF and TOP's own experiences, it is clear that the outcomes of formalization are very dependent on the broader political economic and social conditions.

I would now like to consider implications of community projects like TOP within and on neoliberal cities. Earlier I described Denmark as a "historically welfare-driven, but increasingly neoliberalized state." The 'welfare commitment' remains - even if it is occasionally co-opted in the serve of the larger neoliberal agenda (Roy 2018: 290). The work of urban political ecologists like Rosol (2012) and McClintock (2014) show how gardens in some cities provide services that prop up, if inadvertently, cities undergoing neoliberalization. A municipal respondent countered this postulation, referring to the strong influence of labor unions and explaining,

It's not like in New York City where [volunteers] help maintain their green areas (...) in what should actually be paid work. (...) [In Copenhagen] it's more like they do their own projects. They come with their own ideas, and we try to help them. (...) I think the whole 'volunteer' idea is going to be transformed into 'active citizenship'.

Whether 'active citizenship' serves discursively to obscure processes such as described by Rosol is worth looking into. Meanwhile, TOP more obviously contributes to the neoliberalizing city in other ways. If less through its 'gap filling', then more so given its contribution as a valued 'green space' to ongoing gentrification in a neighborhood and city where the housing sector is increasingly deregulated, weakening protections and undermining housing justice (Larsen and Lund Hansen 2015; Rutt and Loveless 2018). What gentrification entails for local initiatives, in the sense of new residents maintaining these spaces that attracted them to a location in the first place, deserves investigation, but the productivity imperative often embraced by the middle class spells trouble. Roy's (2018: 298) research on state and civic discourses driving an urban garden with a renewal project "suggest that while urban renewal effort (...) is partly guided by state and civic entrepreneurial motivations, it is not explicitly guided by a malicious state-intent to punish the poor." I strongly believe the municipal representatives I have interacted with over the years embody altruistic motivations and dedication to the cause of greening our cities for diverse social and environmental benefits. Yet as Roy concludes, "However, in the end these multiple discourses co-produce an unequal local ecology that proves to be enabling for some and disabling for other social groups" (2018: 298). And as one municipal respondent explained of their colleagues, "They've kind of been avoiding the discussion of gentrification with green spaces. They've been talking about gentrification in relation to prices of apartments, tourism, Airbnb, shops, stuff like that... and I think because (...) they are so pro-green spaces, that they... they don't care."

In terms of neoliberalization's implications for community projects like TOP, I have already discussed in relation to formalization the risks of local project dependency on the whims of a state that is following a neoliberal trajectory. In Copenhagen, austerity - including budget cuts - have led to the shutdown of some projects (and perhaps prevented new ones from forming) not least through the firing of the coordinator position. Budget caps and cuts also likely reduced the various pots of money projects like TOP rely on to sustain themselves. Taking a broader perspective, I want to reiterate some of those driving forces contributing to project 
failure - starting with our lack of need. Shared interests and value-based motivation is substantial; contemporary environmental psychology demonstrates that values are hugely important in driving behaviour (Steg and Vlek 2009). Yet the motivation of need is undeniable. Reflecting on degrowth toward 'radical urban imaginaries', Alexander and Gleeson (2019: 159) point out, "It seems that nothing incentivises quite like necessity, and when people are threatened with hunger, they do not wait for the government's permission to grow food." Urban farming is thus common in food 'deserts' and 'swamps' (Meenar and Hoover 2012), which are these days few and far between in Scandinavia. While that should be cause for celebration, not least recollecting food shortages during and after the world wars which expanded the allotment gardening movement, we must attend to the costs of our corporatized and industrialized global food system today, part and parcel of the neoliberal global regime. Denmark imported nearly US\$11 billion in food products in 2018 "for direct consumption" and/or "as raw materials in the food cluster", and this has generally risen over the past decade (Landbrug og Fødevarer 2018). Food imports, with prices artificially suppressed due to capitalism's externalization of environmental costs of production, are also part of Denmark and other countries 'outsourced pollution' and 'invisible emissions' due to the blind spots in current emissions calculations (see Lund et al. 2019 for an analysis of such blind spots in current Danish emissions calculations; also see Sandström et al. 2018 for an analysis of food import carbon emissions in several European countries). This is particularly notable in countries praised for their overall sustainability, like Denmark.

It is surely unpopular to suggest moving along the 'need spectrum' as an overt strategy, but here is where local food sources offer an appealing alternative and a means to reduce urban carbon emissions. And strategies to reduce food imports may contribute to motivation - to supplement diets, to learn about and experiment with food sovereignty. And as research shows, an actual felt 'need' in places like Scandinavia for climate change mitigation and resilience may come sooner than many here are willing to accept (EEA 2019). Little TOP produces very little by way of actual produce. But what is shows is that the desire exists, and this can be nurtured in larger projects that can go hand in hand with regulatory changes to more comprehensively encourage their success.

\section{Enabling convivial and green cities}

In 'western' and relatively wealthy cities we see a rise in the pursuit of urban farming driven by valuebased eco-social ambitions, which are "exploring and prefiguring ecologically feasible futures" (Berglund 2017: 567). What TOP shows is that these social constructs / imaginations are fragile, pulled at by numerous structural conditions confronting individuals and projects at large. These range from our stable and plentiful agricultural imports available at the supermarket, which inhibit us from even approaching a 'need' to grow, to our work culture, a reflection of our capitalist system that inhibits so much potential leisure time by design, locking us in systems of production and/or capital accumulation geared toward consumption. When faced with a choice of what to do with our precious free time, we quickly come to feel that the idea of the garden is more exciting than the reality. We really need time to relax at home, we really need time with closer family and friends. Yet communal trust and cohesion needs as much nurturing as a seed. Were our easy and cheap access to industrially produced food based on extensive importing from around the world cut short, we might feel more inclined and inspired to experiment with greenhouses and supplemental foods on our own or within our communities.

Robin Wall Kimmerer $(2013: 151,154)$ reflects, "Gardens are simultaneously a material and a spiritual undertaking. (...) I wonder if much that ails our society stems from the fact we have allowed ourselves to be cut off from that love of and from the land. It is medicine for broken land and empty hearts." Community projects including of farming offer enormous potential toward the cultivation of convivial neighborhoods, and convivial societies. Conviviality is a "living practice" and in recognizing social relations as "our greatest treasure" (Adloff 2016), we must collectively deliberate upon, challenge and expand what practices of governing are reasonable and desirable in our common spaces, pushing back again the delimitations put upon us under neoliberalism. 
Yet Odell (2019) reminds of the powerful forces working against such aspirations and practices:

In the context of health and ecology, things that grow unchecked are often considered parasitic or cancerous. Yet we inhabit a culture that privileges novelty and growth over the cyclical and the regenerative. Our very idea of productivity is premised on the idea of producing something new, whereas we do not tend to see maintenance and care as productive in the same way.

Similarly, Harvey (2012: xv-xvi) notes,

The traditional city has been killed by rampant capitalist development, a victim of the neverending need to dispose of overaccumulating capital driving towards endless sprawling urban growth no matter what the social, environmental, or political consequences.

Yet urban farming presents important opportunities to engage in convivial activities that can resist urban enclosures so typical to the neoliberal city, through commoning of public space (Anguelovski 2015). As such, and as in the case of TOP, urban farming can be a 'non-capitalist' project demonstrating close ties to the notion and project of degrowth. Urban farming as envisioned by organizations like TOP is also a practice of 'commoning': "connections and relations amongst participants bearing an intrinsic value in and for themselves. These practices are non capitalistic (...) They are new forms of commons" (Kallis 2015: 12). But such spaces "don't just fall from the sky" (Helfrich and Bollier 2015: 75). They are not just collective resources but collective processes. As mentioned, "a resource becomes a commons when it is taken care of by a community or network" (ibid.). And to return to my opening quote, "It's hard to keep voluntary projects alive without life in the space. (...) When there's no life, there's only responsibility left." So reflected a longtime local activist on a recent historical walking tour of (struggles over) green spaces in my neighborhood. I worry sometimes what our current mix of practices and norms entails for our potential toward a degrowth future that includes convivial commons.

Some scholars and practitioners list the ways in which city authorities can promote urban farming within sustainable city agendas (e.g. Dubbeling 2017). This is important, but insufficient. Very few speak directly to broader 'enabling conditions', that is of urban farming within deeply sustainable and just cities of the future. I acknowledged at the start that the nature of the 'community' behind projects like TOP deserves scrutiny. Commons as described by Helfrich and Bollier (2015) stand in resistance to the resource enclosures so widespread since the $19^{\text {th }}$ century and so integral to the project of capitalism from then until today. If I define 'community garden' to include the characteristic of involving the "convergence of individuals - members of the community - joining in garden activities open to the public" (Christensen, Dyg and Allenberg 2018: 233-234) and facilitating exchange "across generations and cultures, societal development, and empowerment" (Mok et al. 2014: 24), then the nature of access is paramount. TOP arguably has some work to do in that regard, not least in recognition of the broader diversity of the neighborhood in which it exists - which it has never fully reflected. For practical but also ideological reasons, we have in some ways 'privatized' or at least narrowed the accessibility of a public space. Horst et al. (2017) helpfully present concrete steps public authorities can take to ease such inadvertent outcomes and promote more just urban farming. And while urban garden scholarship writ large broadly tends to be celebratory, critical scholarship is also emerging (Classens 2014). What scholars of urban farming and greening could be even more attentive to, are the indirect inhibiting conditions related to our food systems, land access models, labor rights and norms, and housing rights and rules. Degrowth policy proposals like universal basic income, work share programs, and reduced working hours (see Kallis 2015) are obvious policy responses with implications for more successful community initiatives like farming. Urban farming is not the panacea for sustainable cities that some current proponents seem to make it out to be. But my wish with this article is to put forth the claim that it can be an integral part of deeply sustainable and just cities of the future.

I conclude this article in the midst of the Covid-19 pandemic. At this moment, policy responses of physical distancing alongside the economic fallout pose new challenges to projects like TOP. But this pandemic, 
while undesired and devastating, also presents learning opportunities toward a degrowth future. It invites us to reconsider what constitutes the essential and the superfluous in our daily lives, the societal implications of our personal choices, and our collective power to preserve life in all forms (FADA 2020). This may bring us back to the garden, and to each other, in new and more committed ways. Yet for deeply sustainable, just, and convivial commons that avoid neoliberal cooption, Danish residents and authorities must embrace enduring legacies, from the social welfare tradition to the rich history of communing in collective living (Larsen 2019) and allotment garden associations. Public authorities in cities around the world must consider the exclusivity and tradeoffs of governance norms while taking justice-based political action at multiple scales, including within agricultural, trade, housing and labor politics. Community activists, garden volunteers and residents at large meanwhile must continue to prefigure and demand the change they wish to see in their cities.

\section{References}

Adloff, F. 2016. Degrowth meets convivialism: pathways to a convivial society. Degrowth.org Website. [accessed April 4 2020] www.degrowth.info/en/2016/08/degrowth-meetsconvivialism-pathways-to-aconvivial-society/.

Alexander, S. and B. Gleeson. 2019. Imagining a prosperous descent. In Alexander, S. and B. Gleeson. Degrowth in the suburbs: a radical urban imaginary. London: Palgrave MacMillan.

Anguelovski, I. 2015. Urban gardening. In D'Alisa, F. Demaria and G. Kallis (eds.). Degrowth: a vocabulary for a new era. London: Routledge.

Berglund, E. 2017. Steering clear of politics: local virtues in Helsinki's design activism. Journal of Political Ecology 24: 566-581.

Christensen, S., P.M. Dyg and K. Allenberg. 2018. Urban community gardening, social capital, and "integration" - a mixed method exploration of urban "integration-gardening" in Copenhagen, Denmark. Local Environment 24(3): 231-248.

Classens, M. 2015. The nature of urban gardens: toward a political ecology of urban agriculture. Agriculture and Human Values 32(2): 229-239.

Covert, M. and A. Morales. 2014. Formalizing city farms: conflict and conciliation. In Mukhija V. and A. Loukaitou-Sideris (eds.). The informal American city: beyond taco trucks and day labor. Cambridge: MIT Press.

D'Alisa, G., F. Demaria and G. Kallis (eds.). 2015. Degrowth: a vocabulary for a new era. London: Routledge.

Dansk Byplanlaboratorium. 1996. Byfornyelse fra gadegennembrud til integreret byfornyelse 10. Byplanhistoriske Noter 31. Copenhagen: Gammel Dok.

Denmark.net. 2020. Allotment gardens. Denmark.net Website. [accessed 11 June 2020] https://denmark.net/allotment-gardens

Dubbeling, M. and H. de Zeeuw. 2011. Urban agriculture and climate change adaptation: ensuring food security through adaptation resilient cities. In K. Konrad Otto-Zimmermann (ed.). Resilient cities: cities and adaptation to climate change. Dordrecht: Springer.

Dubbeling, M. 2017. Sustainable cities require urban agriculture. Meeting of the Minds website. [accessed 23 February 2020] meetingoftheminds.org/sustainable-cities-require-urban-agriculture-20941.

Dyck-Madsen, S. 2004. Kampen om byggeren på Nørrebro 1980. Folkets Hus website. [accessed 4 April 2020]. www.folketshus.dk/byggerbogen/Byggerbogen-webudgave.PDF

EC. 2014. European Green Capital 2014 - Copenhagen. European Commission (EC) website. [accessed 4 April 2020]. http://ec.europa.eu/environment/europeangreencapital/winning-cities/2014-copenhagen

EEA. 2019. The European environment —state and outlook 2020. Knowledge for transition to a sustainable Europe. Copenhagen: European Environmental Agency (EEA).

Elsøe, M.K. 2015. Eksperten guider: her er byens fem fedeste byhaver. Politiken 24 June. [accessed 4 April 2020]. http://politiken.dk/ibyen/byliv/art5580821/Eksperten-guider-Her-er-byens-fem-fedeste-byhaver 
FADA 2020. Collaborative feminist degrowth: pandemic as an opening for a care-full radical transformation. Feminist and Degrowth Alliance (FaDa). Degrowth.org website. [accessed June 25 2019]. www.degrowth.info/en/feminisms-and-degrowth-alliance-fada/collective-research-notebook

Fraser, N. 2016. Contradictions of capital and care. New Left Review 100: 99-117.

Forsyth, T.J. 2003. Critical political ecology: the politics of environmental science. London: Routledge.

Friberg, J. and S.K. Ishøy. 2019. Direktør fyret efter skandalesager. Politiken 20 March. [accessed January 09 2019]. http://politikenbyrum.dk/Navne/art7095393/K\%C3\%B8benhavn-fyrer-adm.-direkt\%C3\%B8ri-Teknik-og-Milj\%C3\%B8forvaltningen

Gomiero, T. 2018. Agriculture and degrowth: state of the art and assessment of organic and biotech-based agriculture from a degrowth perspective. Journal of Cleaner Production 197(2): 1823-1839.

Haaland, L.U.S. 2019. Support ØsterGRO rooftop farm from closure. Online petition. www.skrivunder.net/stot_op_om bevarelsen_af ostergro tagfarm_support ostergro_rooftop_farm_f rom_closur?u=1943043\&s=57619934\&utm_source=fb_share\&fbclid=IwAR2Swkczw1nmThe8dzRDI nOsM30mSSQilgI3hJdMl4SKWv_FDCZ-oOqara0

Hansen, H.J. 2009. Kolonihaveloven var Aukens største politiske sej. Information website. [accessed June 19 2020]. https://www.information.dk/debat/2009/08/kolonihaveloven-aukens-stoerste-politiske-sejr

Halloran, A. and J. Magid. 2013. The role of local government in promoting sustainable urban agriculture in Dar es Salaam and Copenhagen. Geografisk Tidsskrift - Danish Journal of Geography 113(2): 121-132.

Harvey, D. 2000. Spaces of hope. Edinburgh: Edinburgh University Press.

Harvey, D. 2007a. Neoliberalism as creative destruction. The Annals of the American Academy of Political and Social Science 610: 22-44.

Harvey, D. 2007b. Neoliberalism and the city. Studies in Social Justice 1(1).

Harvey, D. 2012. Rebel cities: from the right to the city to the urban revolution. London: Verso.

Helfrich, S. and D. Bollier. 2015. Commons. In D'Alisa, F. Demaria and G. Kallis (eds.). Degrowth: a vocabulary for a new era. London: Routledge.

Henderson, J. and N. Gulsrud. 2019. Street fights in Copenhagen: bicycle and car politics in a green mobility city. London: Routledge.

Heynen, N. 2017. Urban political ecology. In D. Richardson (chief ed.) The International Encyclopedia of Geography. London: Wiley.

Horst, M., N. McClintock and L. Hoey. 2017. The intersection of planning, urban agriculture, and food justice: a review of the literature. Journal of the American Planning Association 83(3): 277-295.

Jensen, L.V., L. R Pedersen, S.S. Hansen and K. Hauxner. 2012. Dyrk din by - fcelles byhaver og frivillighed $i$ byfornyelsen (København). Denmark Ministeriet for By, Bolig og Landdistrikter.

Kallis, G. 2015. Social limits of growth. In D'Alisa, F. Demaria and G. Kallis (eds.). Degrowth: a vocabulary for a new era. London: Routledge.

Kimmerer, R.W. 2014. Braiding sweetgrass: indigenous wisdom, scientific knowledge and the teachings of plants. Minneapolis: Milkweed Editions.

Kolonihaveforbundet. n.d The history of the colony garden movement. Association of Allotment Gardens website. (accessed 20 May 2020). http://kolonihaveforbundet.dk/kolonihaveforbundet/omos/kolonihavebevaegelsens-historie

Kolonihaveforbundet. 2019. Kolonihaveloven- Resultater. Website. [accessed 19 June 2020]. kolonihaveforbundet.dk/kolonihaveforbundet/om-os/resultater/

KK. 2009. A metropolis for people. Gehl Architects and Technical and Environmental Administration, København Kommune (KK).

KK. 2012a. Policy for disadvantaged areas of Copenhagen. Technical and Environmental Administration. Københavns Kommune (KK). 
KK. 2012b. CPH 2025 Climate Plan. Technical and Environmental Administration, København Kommune (KK).

KK. 2013. Green roofs Copenhagen. Technical and Environmental Administration, København Kommune (KK).

KK. 2015a. Business and growth policy. København Kommune (KK).

KK. 2015b. Bynatur I københavn 2015-2025. Technical and Environmental Administration, København Kommune (KK).

KK. 2019. Liveable green city. København Kommune (KK). Website. [accessed 10 April 2020]. www.international.kk.dk/artikel/liveable-green-city

Laage-Thomsen J. and A. Blok. 2020. Varieties of green: on aesthetic contestations over urban sustainability pathways in a Copenhagen community garden. Environment and Planning E: Nature and Space https://doi.org/10.1177/2514848620902806.

Landbrug og Fødevarer. 2018. Udenrigshandel 2014-2018. Website. [accessed 10 April 2020]. lf.dk/tal-oganalyser/udenrigshandel.

Lang, M. 2017. Degrowth - unsuited for the Global South? Alternautas 4(1): 100- 113.

Larsen, C.A. and J.G. Andersen. 2009. How new economic ideas changed the Danish welfare state: the case of neoliberal ideas and highly organized social democratic interests. Governance 22(2): 239-261.

Larsen, H.G. 2019. Three phases of Danish cohousing: tenure and the development of an alternative housing form. Housing Studies 34(8): 1349-1371.

Larsen, H.G. and A. Lund Hansen. 2015. Commodifying Danish housing commons. Geografiska Annaler: Series B Human Geography 97(3): 263-274.

Larsen, J.E. and I.H. Möller. 2013. The increasing socioeconomic and spatial segregation and polarization of living conditions in the Copenhagen metropolitan area. Presentation to RC 19 Annual Conference of Research Committee 2013, Budapest, Hungary, 22-24 August.

Lauritsen, D.H. 2015. Green roofing Copenhagen. State of Green website. [accessed August 2 2019]. www.stateofgreen.com/en/partners/state-of-green/news/green-roofing-copenhagen

Lund J.F., A. Bjørn, M.B. Simonsen, S.G. Jacobsen, A. Blok and C.L. Jensen. 2019. Outsourcing og omstilling: de danske drivhusgasudledninger genfortolket. Djøf Forlag. Samfundsøkonomen 4/2019.

McClintock, N. 2014. Radical, reformist, and garden-variety neoliberal: coming to terms with urban agriculture's contradictions. Local Environment 19(2): 147-171.

Meenar, M.R. and B.M. Hoover. 2012. Community food security via urban agriculture: understanding people, place, economy, and accessibility from a food justice perspective. Journal of Agriculture, Food Systems, and Community Development 3(1): 143-160.

Mok, H., V.G. Williamson, J.R. Grove, K. Burry, S.F. Barker and A.J. Hamilton. 2014. Strawberry fields forever? Urban agriculture in developed countries: a review. Agronomy for Sustainable Development 34: 21-43.

Nightingale, A. 2005. "The experts taught us all we know": professionalisation and knowledge in Nepalese community forestry. Antipode 37(3): 581-604.

Nørrebro Lokaludvalg 2019. About us. Webpage. [accessed 04 April 2020]. noerrebrolokaludvalg.kk.dk/omlokaludvalget/

Odell, J. 2019. How to do nothing: resisting the attention economy. Brooklyn: Melville House.

Områdefornyelsen Nørrebro 2014. Kvarterplan 2014-2019. Website. [accessed 04 April 2020]. kk.sites.itera.dk/apps/kk_pub2/pdf/1181_xzoDqpuA2A.pdf

Peck, J. and A. Tickell. 2002. Neoliberalizing space. Antipode 34(3): 380-404.

Pedersen, M.L. and J.M. Lindstad. 2011. Første Led I Fødekceden? En undersøgelse af børn og unge i kriminelle grupper. Rapport. Denmark Justitsministeriet.

Project Udenfor. 2012. Report on homeless migrants in Copenhagen. Copenhagen: Udenfor Foundation. 
Ritzau. 2015. Nu findes der 100 byhaver i Danmark. Politiken 27 July. [accessed 4 April 2020]. www.politiken.dk/forbrugogliv/boligogdesign/bolighaven/art5583860/Nu-findes-der-100-byhaver-iDanmark

Robbins, P. 2012. Political ecology: a critical introduction. Oxford: Wiley-Blackwell.

Roe, M. and I. Mell. 2013. Negotiating value and priorities: evaluating the demands of green infrastructure development. Journal of Environmental Planning and Management 56(5): 650-673.

Rosenberg, E. 2019. Stop nedlæggelse af grøn frivillighed i København. Online signature petition. [accessed May 012020$] \quad$ www.skrivunder.net/stop_nedlaggelse_af_gron_frivillighed_i kobenhavn__bevar_grasningslaug_byhaver_bilaug_hojbede_hundparker_og_frivillig_naturpleje

Rosol, M. 2012. Community volunteering as neoliberal strategy? Green space production in Berlin. Antipode 44(1): 239-257.

Roy, P. 2018. "Welcome in my backyard"...but on my terms: making sense of homeless exclusion from renewed urban spaces in Copenhagen. GeoJournal 83: 289-304.

Rutt, R.L. and S. Loveless. 2018. Whose Park? The forty-year fight for Folkets Park under Copenhagen's evolving urban managerialism. People, Place and Policy 12(2): 99-117. summary

Sandström, V., H. Valin, T. Krisztin, P. Havlík, M. Herrero and T. Kastner. 2018. The role of trade in the greenhouse gas footprints of EU diets. Global Food Security 19: 48-55.

Schlosberg, D. and R. Coles. 2016. The new environmentalism of everyday life: sustainability, material flows and movements. Contemporary Political Theory 15: 160-181.

Schmidt, G. 2015. Space, politics and past-present diversities in a Copenhagen neighbourhood. Identities 23(1): 51-65.

Schmidt, G. 2017. Going beyond methodological presentism: examples from a Copenhagen neighbourhood 1885-2010. Immigrants and Minorities 35(1): 40-58.

Schmidt, G. 2019. Nørrebro is lost. Presentation delivered October 23, 2019 at the University of Copenhagen, Denmark.

Steg L. and C. Vlek. 2009. Encouraging pro-environmental behaviour: an integrative review and research agenda. Journal of Environmental Psychology 29: 309-317.

Steiger, T. 2017. Cycles of the Copenhagen squatter movement: from Slumstormer to BZ Brigades and the Autonomous Movement. In Martínez López, M.A. (ed.) The urban politics of squatters' movements. London: Palgrave. Pp. 165-186.

Svarstad, H. and T.A. Benjaminsen. 2020. Reading radical environmental justice through a political ecology lens. Geoforum 108: 1-11.

Taguchi, M. and G. Santini. 2019. Urban agriculture in the Global North and South: a perspective from FAO. Field Actions Science Reports 20: 12-17.

Tubridy, D. 2020. Green climate change adaptation and the politics of designing ecological infrastructures. Geoforum 113: 133-145.

Visit Copenhagen 2020. Places to eat: Gro Spiseri. Website. (accessed 10 December 2019). www.visitcopenhagen.com/copenhagen/planning/gro-spiseri-gdk1014228.

Wang, L.F. 2018. Københavns Kommune nedlægger én stilling og må derfor lukke 39 grønne frivilligprojekter. Information website. [accessed January 06 20]. www.information.dk/indland/2018/12/koebenhavnskommune-nedlaegger-stilling-maa-derfor-lukke-39-groenne-frivilligprojekter\#kommentarer

Zucchino, D. 2016. 'I've become a racist': migrant wave unleashes Danish tensions over identity. New York $\begin{array}{llllll}\text { Times } & 5 & \text { September. } & \text { [accessed } & 4 & \text { June }\end{array}$ https://www.nytimes.com/2016/09/06/world/europe/denmark-migrants-refugees-racism.html 